\title{
Identification and Characterization of S-RNases in Japanese Plum Genotypes
}

\author{
Rauny O. de Souza ${ }^{1}$, Marco A. Dalbó ${ }^{2}$, Eugenia J. B. Braga ${ }^{1} \&$ Valmor J. Bianchi ${ }^{1}$ \\ ${ }^{1}$ Federal University of Pelotas, Campus Capão do Leão, RS, Brazil \\ ${ }^{2}$ EPAGRI-Videira Experimental Station, Videira, SC, Brazil \\ Correspondence: Rauny O. de Souza, Federal University of Pelotas, Campus Capão do Leão, RS, Brazil. Tel: \\ 55-849-946-0550. E-mail: rauny87@hotmail.com
}

Received: April 19, 2019 Accepted: May 28, $2019 \quad$ Online Published: July 31, 2019

doi:10.5539/jas.v11n11p233 URL: https://doi.org/10.5539/jas.v11n11p233

\begin{abstract}
Many species of the genus Prunus exhibit the gametophytic self-incompatibility system, governed by the $S$-locus, that encode S-Ribonucleases in the pistil, and are able to degrade the RNA of the pollen tubes when the $S$-haplotypes of both gametophytes are the same, preventing the fertilization of the oosphere. The objective of this study was to identify and characterize the S-alleles of Japanese Plum genotypes to verify groups of reproductive compatibility. Isolation, amplification and DNA sequencing were performed to obtain an allelic profile of the genotypes. Combinations of $\mathrm{PC} 1$ and $\mathrm{PC} 2$ primers identified $95 \%$ of the genotypes. After sequencing, the ' $S$ ', ' $S$ ', ' $S$ ' ' and ' $S$ ' alleles were obtained with an identity greater than $90 \%$, compared to the NCBI sequences. PC2 was more extensive in identifying the $S$-alleles in the $S$-RNases coding region, generating larger fragments than PC1. In this way, it was possible to generate three groups of genotypes with $S$-alleles of the same size with PC2: Group 1 (Selection Embrapa A19, Selection Embrapa A28, Black Amber Black, Fortune, Roysum, SC-7 and Zafira); and Group 2: (Selection Embrapa A7, Carazinho, Sanguínea, Laroda, SC-15 and Rebelatto) and Group 3 (Selection Ameixa 86-13, Golden King, Letícia and Robusto). Each primer combination amplified only one allele per genotype, suggesting the development of specific primers to amplify the $S$-alleles in each genotype. The identification and characterization of the alleles allow the use of genotypes compatible with each other, considering the floral synchrony of the genotypes, besides providing information for the management of the breeding processes in Japanese Plums.
\end{abstract}

Keywords: plant reproduction, genetics, Rosaceae, Prunus salicina Lindl

\section{Introduction}

Sexual reproduction is an important aspect achieved by the Plant Kingdom. During this process, evolutionary mechanisms involving the union of half the genome of both parents, through sexual gametes [haploid (n) cells] and genetic recombination, allows the generation of segregating individuals, which is an important characteristic for species survival in different environmental pressures. Moreover, the use of reproductive structures (male and female gametophytes) favored genetic diversity when compared with asexual reproduction (Gonçalves \& Lorenzi, 2011).

Vegetables developed two strategies of sexual reproduction: autogamy and allogamy. Autogamous plants have developed the ability to self-pollinate and allogamous plants evolved the reproductive process for the need of cross-pollination. This strategy allowed for the development of sexual self-incompatibility (sporophytic and gametophytic) to favor genetic variability, avoiding inbreeding (De Nettancourt, 2001; Schifino-Wittmann \& Dall'agnol, 2002).

Sporophytic Self-Incompatibility (SSI) can be observed for example in the family Passifloraceae (Madureira, 2009) and Brassicaceae (Havlícková et al., 2014). The specificity in SSI regarding the rejection of the male gametophyte in pollination depends on the maternal tissue, the carpet [diploid (2n) tissue covering the pollen grain]. Pollen deposited on stigma carpet comes in contact with their cells, signaling for rejection or acceptance of the pollen tube growth. Enzymes contained in the pistil will prevent the growth of the pollen tubes if they have the same genetic characteristics of the pistil (Schifino-Wittmann \& Dall'agnol, 2002). 
The system of Gametophytic Self-Incompatibility (GSI) can be found in the families Solanaceae, Scrophulariaceae, and Rosaceae, and is characterized by the recognition of the pistil cells when they come in contact with pollen grains (n), cells or pollen tubes. Moreover, the enzymes produced during GSI interaction degrade the cells of the male gametophytes (Aguiar et al., 2015). Furthermore, the enzymes or female haplotype that causes cytotoxicity and disrupts the growth of pollen tubes are called S-ribonucleases enzymes (S-RNases) and are produced from the expression of genes involved in the sterility of sex cells in many plant species.

RNases are composed of N-glycosylated protein sites and histidine residues (conserved amino acid blocks) that act as a peptide signal (Matsuura et al., 2001; Mcclure et al., 2011), and due to the active site CAS I and CAS II, they are able to cleave single strand RNA (substrate) (Luhtala \& Parker, 2010) carrying out a role of self-pollen rejection as well as defense against the growth of infectious structures (Mittler et al., 2011).

Under favorable conditions of temperature and humidity, pollen tubes grow within the stigma, and a range of biochemical interactions take place between the pollen tubes and the cells of female tissue. In compatible interactions, RNases act on the cellular apoplastic, especially on the stigma papillae, and they are massively absorbed by the clathrin vesicles of the pollen tube (Williams, Wu, Li, Sun, \& Kao, 2015). When there is a positive interaction for reproduction, F-box proteins (SFB) contained in the male gametophyte facilitate the fertilization of the oosphere. The F-box proteins degrade RNases by ubiquitination via $26 \mathrm{~S}$ proteasomes and favor the growth of the pollen tube (Zang et al., 2007). Both RNases and F-Box are the product of the expression of GSI genes contained in a single multi-allelic gene locus called $S$-alleles or Sterility loci encoding the female S-haplotype (S-RNase) and the male S-haplotype (S-Fbox) (Hua et al., 2008; Williams et al., 2015).

The female $S$-haplotype encodes the RNases present conserved regions (C): (C1, C2, C3, C4, and C5). Moreover, between $\mathrm{C} 2$ and $\mathrm{C} 3$ there is a common in Rosaceae Hypervariable region (RHV) and there are two histidine residues responsible for the enzymatic activity and degradation of RNA from pollen grains (Takayama \& Isogai, 2005). In Rosaceae, the conserved regions have been investigated for the identification of genes encoding RNases and for polymorphism of the allelic series in the S-locus within the species (Ushijima et al., 1998).

The Prunoideae tribe, which belongs to the Rosaceae family, share the GSI trait and several studies have identified the RNases in Prunus dulcis (López et al., 2004) and Prunus salicina (Carrasco et al., 2012). These studies have intensified in recent years, highlighting the importance and confirmation of S-haplotypes in reproduction. Genotypes with desired agronomic characteristics have been investigated to access the breeding capabilities and to select self-fertility genotypes or uncover alleles that are possibly associated with self-fertility (Marchese et al., 2008; Fernández i Martí et al., 2014).

The identification and characterization of the allelic series (S-alleles), which is named ' $S$ ', ' $S$ ', ' $S$ ', ' $S$ ', and ' $S$ ' or ' $S$ ', ' $S$ ', ' $S$ ', ' $S$ ', and ' $S$ ', that encode the RNases in the stigma of the Japanese Plum cultivars, can help to manage orchards, since the cultivation of genotypes with different alleles may increase fertilization and effective fruit set (Ushijima et al., 1998; De Nettancourt, 2001; Kondo et al., 2002; De Conti et al., 2013; Sassa, 2016). Molecular studies to understand the reproductive process in Prunus species are focused on the identification and characterization of S-RNases genes through tools like Polymerase Chain Reaction (PCR) and DNA sequencing.

The aim of this study was to identify and characterize the allelic series of the S-RNases for Prunus salicina Lindl. cultivars to verify the possible reproductive (in)compatibility among genotypes under study.

\section{Material and Methods}

\subsection{Plant Material for Total DNA Isolation}

Twenty genotypes of $P$. salicina were used for S-RNases analysis. Young, expanded and healthy leaves were collected from Japanese Plum genotypes: 'Selection Embrapa A19', 'Selection Embrapa A28', 'Selection Embrapa A7', 'Black Amber', 'Carazinho', 'Sanguínea', 'Bruce', 'Laroda', 'Piamontesa', 'Selection Ameixa 86-13' (SA 86-13), 'Golden King', 'Chatard', 'Letícia', 'Robusto', 'Fortune', 'Roysum', 'SC-15', 'SC-7', 'Zafira' and 'Rebelatto'. The plant material was collected from the EPAGRI collection-Videira Experimental Station (Videira, Santa Catarina-Brazil).

The DNA was extracted according to the method proposed by Doyle \& Doyle (1991). DNA from the samples was quantified in NanoVue ${ }^{\circledR}$ spectrophotometer to verify purity and concentration. After, we used $1 \%$ agarose gel electrophoresis to confer band integrity. Moreover, the gel was stained with ethidium bromide and visualized under UV light on the Vilber Lourmat ${ }^{\mathbb{B}}$ E-Box-1000 transilluminator. 


\subsection{Polymerase Chain Reaction (PCR) for S-allele Amplification}

For the PCR reactions, $20 \mathrm{ng}$ of DNA was taken from each sample and PROMEGA ${ }^{\circledR}$ kit reagents were used in the following concentrations: GoTaq (1.25U Taq DNA polymerase), 1x PCR Buffer (25 mM Tris-HCl, $\mathrm{pH} 9.0$ ), $1.5 \mathrm{mM} \mathrm{MgCl} 2,200 \mu \mathrm{M}$ of each dNTP, $0.4 \mu \mathrm{M}$ of each primer (Table 1), and Milli-Q water to bring the final volume to $25 \mu \mathrm{l}$. The thermocycler (Biocycler MG96G) was used to amplify DNA at an initial temperature of $94{ }^{\circ} \mathrm{C}$ for 5 minutes, followed by 40 cycles of $94{ }^{\circ} \mathrm{C}$ for 1 minute, $59{ }^{\circ} \mathrm{C}$ for 2 minutes, at $72{ }^{\circ} \mathrm{C}$ for 3 minutes, and a final cycle of $72{ }^{\circ} \mathrm{C}$ for $10 \mathrm{~min}$. The amplified PCR product was subjected to $1.5 \%$ agarose gel electrophoresis at $5 \mathrm{~V} \mathrm{~cm}^{-1}$, and we used the DNA ladder $100 \mathrm{bp}$ as a molecular marker (Ludwig ${ }^{\mathbb{B}}$ ), and the samples were stained with ethidium bromide and visualized under UV light.

Table 1. Primers used in the amplification of S-RNases alleles by PCR of 20 genotypes of Prunus salicina

\begin{tabular}{llll}
\hline PRIMERS $^{*}$ & SEQUENCE $\left(\mathbf{5}^{\prime} \rightarrow \mathbf{3}^{\prime}\right)$ & T $\left({ }^{\circ} \mathbf{C}\right)$ & REFERENCE \\
\hline PRU-C2 & F: CTATGGCCAAGTAATTATTCAAACC & & Tao et al. (1999) \\
PCE-R & R: TGT TTG TTC CAT TCG CYT TCC C & 59 & Yamane et al. (2001) \\
PRU-C5 & R: TACCACTTCATGTAACAACTGAG & & Tao et al. (1999) \\
\hline
\end{tabular}

Note. *Primer Combination: PC1 = PRU-C2 + PCE-R; PC2 = PRU-C2 + PRU-C5; F: forward; R: reverse.

\subsection{Sequencing of S-RNases From the PCR Product and in Silico Analysis}

The PCR products (bands) were purified with Thermo Scientific ${ }^{\circledR}$ Gene JET PCR Purification kit. The DNA samples were standardized with concentrations of $50 \mathrm{ng} \mathrm{ul}^{-1}$ and sent for sequencing. Sanger sequencing method was performed using the Genetic Analyzer 3500 apparatus (Applied Biosystems, USA) from the Laboratório de Genômica Estrutural of UFPEL.

Sequencing result analyzes were run in silico to investigate the quality of the bases, and to remove the low-quality nucleotides the $\mathrm{Chromas}^{\circledR}$ software was used. The data were aligned in Clustal X2 software (Thompson et al., 1997) to observe consensus sequences. Finally, the sequences were compared in the database of the National Center for Biotechnology Information (NCBI) with nucleotide sequences already deposited through the tool BLASTN.

\section{Results}

\subsection{PCR Analysis and Identification of Female S-haplotypes of Japanese Plum Genotypes}

DNA amplification in Japanese Plum genotypes showed differences in the sizes of the fragments (alleles) produced from PRU-C2+PCE-R (PC1) and PRU-C2+PRU-C5 (PC2) primer combinations. These primers were designed from the conserved regions ( $\mathrm{C} 2$ through $\mathrm{C} 5$ ) and were used in many species of the genus Prunus to present the genome amplification capacity of the conserved region of S-RNases and RHV (Tao et al., 1999).

The combination of PRU-C2+PCE-R (PC1) primers allowed the amplification of $S$-RNases alleles in $95 \%$ of the analyzed cultivars, except for 'Bruce'. The selections and cultivars evaluated presented alleles or bands with fragment sizes varying between 250 and 1200 base pairs (bp). It was verified that most of the genotypes amplified only one allele, except the 'Selection Embrapa A7' and 'Carazinho', which presented two alleles each (300 and 250 bp, 400 and 300 bp, respectively). The genotypes 'Embrapa A19', 'Embrapa A28', and cultivars Fortune, SC-7, Zafira, and Black Amber presented 1200 bp bands. The genotypes SA 86-13, Golden King, Letícia, Robusto and Piamontesa presented bands with approximately $400 \mathrm{bp}$ and Chatard had shown $350 \mathrm{bp}$. The cultivars Sanguínea, Laroda, SC-15, SC-7, and Rebelatto showed allele with 300 bp (Figure 1). 


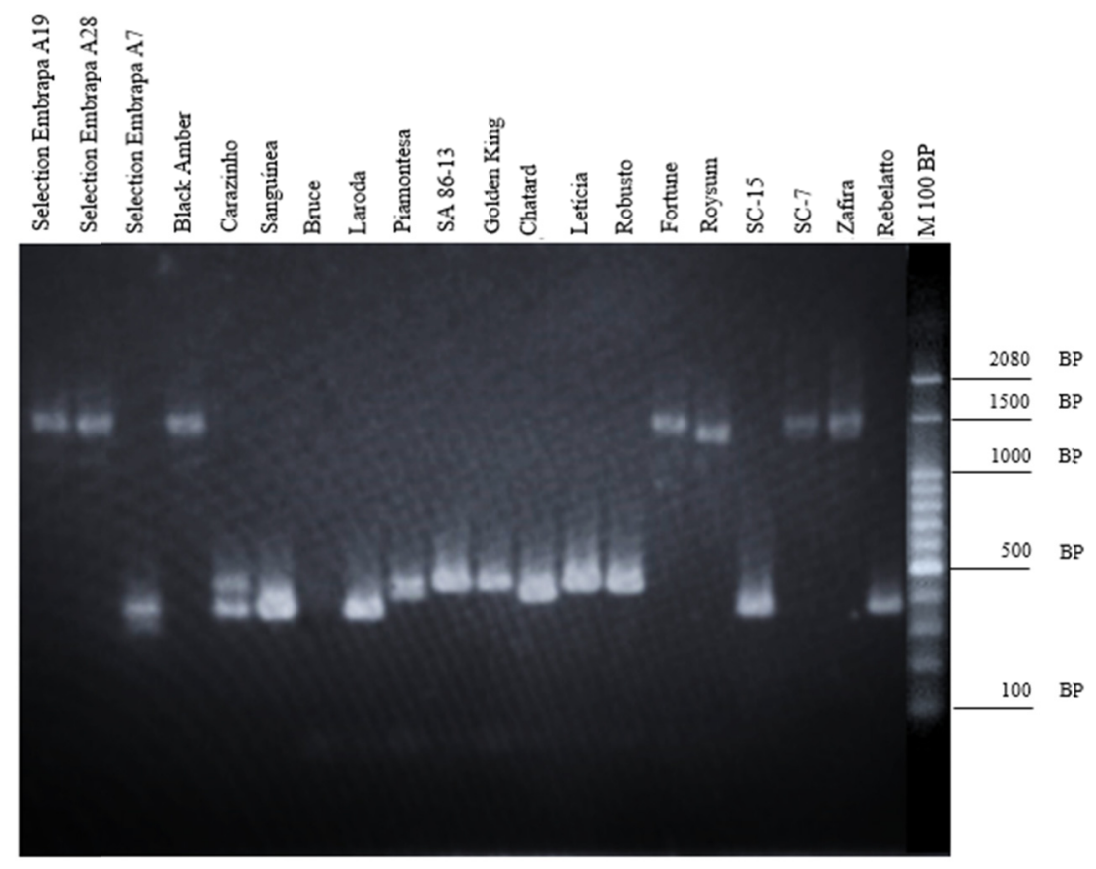

Figure 1. Identification of S-RNases through PC1 (PRU-C2 + PCE-R) used in Japanese Plum genotypes; M: 100 bp Marker

The size of the amplified alleles varied between 1300 and 600 bp with the PRU-C2+PRU-C5 primers, obtaining an amplification of $95 \%$ of the individuals evaluated. The absence of bands in the gel continued to be observed in 'Bruce'. The $S$-RNase allele amplification pattern with approximately $1300 \mathrm{bp}$ was observed in the 'Selection Embrapa A19', 'Selection Embrapa A28', 'Fortune', 'Black Amber', 'Roysum', 'SC-7' and 'Zafira'. The genotypes 'SA 86-13', 'Golden King', 'Letícia' and 'Robusto' presented alleles with 700 bp. 'Piamontesa' and 'Chatard' presented alleles of $650 \mathrm{bp}$, and the allele with 600 bp were observed in 'Selection Embrapa A7', 'Carazinho', 'Sanguínea', 'Laroda' and 'SC-15' and 'Rebelatto' (Figure 2).

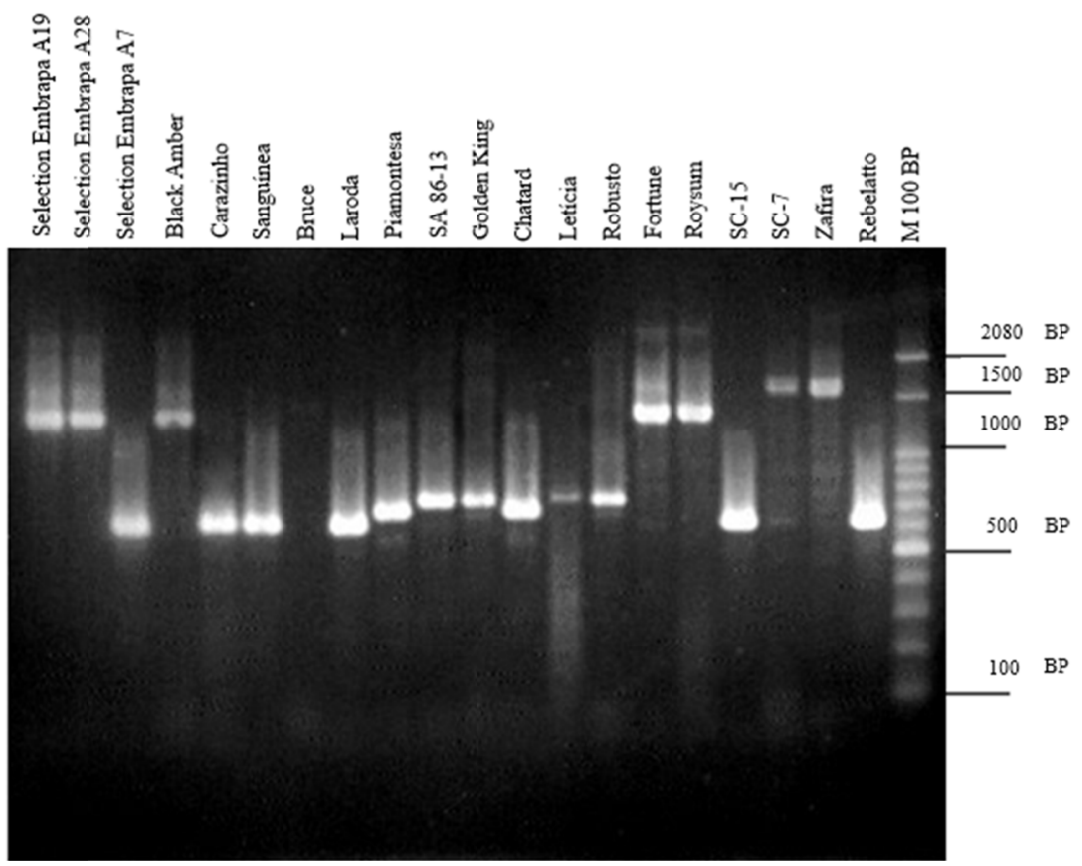

Figure 2. Identification of $S$-RNases alleles through PC2 (PRU-C2 + PRU-C5) used in Japanese Plum genotypes. M: 100 bp Marker 
We have found that groups of $S$-alleles were formed based on the size of the amplified DNA fragments within the female $S$-haplotypes in the Plum genotypes (Table 2).

Table 2. Groups of Japanese Plum genotypes based on the size of the amplified fragments of the $S$-RNases for the combinations of primers 1 and 2 (PC1 and $\mathrm{PC} 2$, respectively)

\begin{tabular}{lllllll}
\hline \multicolumn{5}{c}{ Genotypes groups formed from the size of the S-alleles } \\
\hline G1 & G2 & G3 & & \multicolumn{3}{c}{ Groups formed from PC2 } \\
\cline { 1 - 2 } \cline { 5 - 6 } Selection Embrapa A19 & Sanguínea & Piamontesa & & Selection Embrapa A19 & Selection Embrapa A7 & SA 86-13 \\
Selection Embrapa A28 & Laroda & SA 86-13 & & Selection Embrapa A28 & Carazinho & Golden King \\
Black Amber & Rebelatto & Golden King & & Black Amber & Sanguínea & Letícia \\
SC-7 & $*$ & Letícia & & Fortune & Laroda & Robusto \\
Zafira & $*$ & Robusto & & Roysum & SC-15 & $*$ \\
$*$ & $*$ & $*$ & $*$ & Rebelatto & $*$ \\
\hline
\end{tabular}

\subsection{Analysis of the Sequencing of S-RNases of Japanese Plum Genotypes}

Data obtained in silico allowed for the characterization of 15 genotypes and at least five $S$-RNases alleles: ' $S$ ' or ' $S^{A},{ }^{\prime}$ ' $S$ ', ' $S$ ' and ' $S$ ' of the species Prunus salicina $\mathrm{L}$. The ' $S$ ' ' presented $100 \%$ and $99 \%$ identity when the PC1 combination was used for the 'Selection Embrapa A19' and 'Selection Embrapa A28', respectively. When the combination PC2 was used, only the 'Selection Embrapa A28' showed 100\% identity with the ' $S$ ' allele (Table A1).

The identity of the ' $S$ ' allele deposited in the NCBI was found in the cultivars Black Amber, Fortune, and Roysum. With the PC1 combination, the percentages of identity of the ' $S$ ' ' allele identified and compared to the NCBI sequences were $96 \%, 94 \%$ and $98 \%$ in Black Amber, Fortune, and Roysum. Using the PC2 combination, Black Amber had the lowest percentage of identity (94\%) with the ' $S$ ' ' allele compared to Fortune, and Roysum, with $99 \%$ and $97 \%$ identity with the ' $S$ ' allele, respectively (Table A1).

The cultivars Sanguínea, Laroda, SC-15, and Rebelatto presented common alleles called ' $S$ ' ' and their percentage of identity was $99 \%, 99 \%, 98 \%$, and $96 \%$, respectively when PC1 was used. of alleles amplified with PC2, the percentage of identity was lower than the alleles obtained with PC1 with values of $95 \%, 94 \%, 94 \%$ and $97 \%$ in the analyzed genotypes.

While comparing the data obtained in the present research and NCBI, the ' $S^{h}$ ' allele was identified in 'SA 86-13', 'Golden King', 'Letícia' and 'Robusto'. Using the combination of primers PC1 and PC2, the identity values were $96 \%, 95 \%, 97 \%, 98 \%$, and $100 \%, 97 \%, 98 \%, 99 \%$, respectively. Sequence analysis of the Piamontesa and Chatard genotypes showed that they had nucleotide sequences identical to the ' $S$ ' ' allele with $99 \%$ and $93 \%$ identity, respectively, when using PC1 and 99\% identity in both cultivars using PC2. For all results obtained from the sequencing (Table A1), it was observed that the e-value was zero or close to zero, confirming the degree of identity and significance of the data obtained in comparison with the sequences already deposited in the NCBI.

Table 3. Groups based on the sequencing of S-RNases from PC2 in Japanese Plum genotypes

\begin{tabular}{lll}
\hline & Genotypes groups with the same $\boldsymbol{S}$-alleles based on PC2 \\
\hline G1-Allele $S^{c}$ & G2-Allele $S^{i}$ & G3-Allele $S^{h}$ \\
\hline Selection Embrapa A19 & Sanguínea & SA 86-13 \\
Selection Embrapa A28 & Laroda & Golden King \\
Black Amber & SC-15 & Letícia \\
Fortune & Rebelatto & Robusto \\
Roysum & $*$ & $*$ \\
\hline
\end{tabular}




\section{Discussion}

\subsection{PCR Analysis and Identification of S-RNases in Japanese Plum Genotypes}

The PCR products generated from the Primers Combination 2 (PC2) were larger than those obtained with Primers Combination 1 (PC1) in all genotypes. PC1 amplified DNA fragments between the $\mathrm{C} 2$ and $\mathrm{C} 3$ regions (Yamane et al., 2001), and the PC2 anchors the C2 and C5 conserved regions, thus justifying the difference among DNA fragments of the female S-haplotypes identified in the study.

$\mathrm{Gu}$ et al. (2015) obtained an amplification pattern for the conserved regions of the S-RNases alleles similar to ours when they used the combinations of primers [PMT2 + PCE-R and PRU-C2 + Pp-SR]. The authors observed that the largest DNA fragments were produced from the combination that covered the $\mathrm{C} 1$ to $\mathrm{C} 5$ regions and the smallest fragments were observed covering the $\mathrm{C} 1$ to $\mathrm{C} 3$ regions. The PRU-C2 + Pp-SR primers showed a larger fragment amplified covering the region that coded for the $S$-RNase in both the Prunus and Malus genus, as a function of specificity and the capacity to amplified the $S$-alleles linked to GSI in this genus.

The amplification of $S$-haplotype alleles for P. salicina may present different results among the cultivars when using different Primers Combination (PC), as shown in this study. 'Bruce', for example, did not have the female S-haplotypes alleles amplified with the two PC. This condition may be associated with the specificity of the primers and the lack of complementarity among primers sequence with the nucleotides that coding for $S$-RNases in this genotype, because the primers were not specifically designed for P. salicina genome but based on the Prunus cerasus (Yamane et al., 2001) and Prunus avium S-allele sequences (Tao et al., 1999). In addition, most of the genotypes amplified a single band, according to the electrophoresis analysis (Figure 1 and 2), reinforcing the idea that the specificity of the primers is restricted for some species and genotypes of the genus Prunus.

Studying the characteristics of GSI, Beppu et al. (2005) observed that at least two bands were amplified in cultivars of $P$. salicina, confirming with Guerra et al. (2010) that they identified the ' $S S^{c}$ ' alleles in the cultivars Black Amber, Fortune and Laroda and the ' $S$ ' $S^{h}$ ' alleles in 'Laettitia' (called 'Letícia' in this research). However, in our research we could not identify the ' $S^{b}$ ' allele in Black Amber, Fortune and Laroda, nor the Allele ' $S$ ' in Letícia, when we performed the characterization of these same cultivars in the present study. Let us state that it is necessary to develop specific primers for Japanese plum S-haplotypes grown in brazilian orchards. It is important to highlight that the expression of genes is conditioned to internal factors such as phytosanitary status, metabolism and nutrition, and external factors such as temperature, humidity and location of genotypes, where they are inserted as generators and influences of responses such as the present research, not characterizing the second allele in Japanese plum genotypes.

Mota et al. (2010) obtained an allelic profile similar to the present study when they tested eleven Japanese plum cultivars with the same combinations of primers used in our research. However, they observed that the cultivars Pluma 7, The First and two distinct Gulfblaze genotypes (Guaíba clone and São Paulo clone) produced a single allelic band with PC1 and the same with 'The First' and 'Gulfblaze Guaiba' when using PC2, confirming the need to perform a new design of Japanese plum specific primers in order to avoid such distortions between the generated data. However, it was found that the fragments generated in all PC2 genotypes were larger in comparison to $\mathrm{PC} 1$.

It was observed that the occurrence of null alleles within the same gene locus may be an important factor to be considered (Mota et al., 2010). Null alleles are associated with modifications in DNA by deletion or addition of nucleotides at the sites where primers anchor, hampering primer binding in the target sequence and the amplification (Suzuki \& Bird, 2008; Fernández et al., 2009; Dabrowski et al., 2015). Moreover, the overlap of amplified bands in the gel may be an impediment to the visualization of the second band in the gel, which was observed in the cultivar Shiro by Halász et al. (2007).

The appearance of an amplified fragment of DNA for self-incompatibility is common in almond cultivars (Prunus dulcis). Furthermore, Kodad et al. (2008) observed this in four of the fourteen almond cultivars. The same authors emphasized that this type of result can occur as a function of null loci for GSI in some species of the genus Prunus.

De Conti et al. (2013) obtained the S-allelic profile of Japanese Plum cultivars using the same PC of the present research. The authors verified the presence of a single allelic band in the cultivars Gulf Rubi, Amarelinha, Harry Pickstone, Selection 19, and Methley. They highlighted the possible homozygosis for the S-alleles within the loci chromosomes responsible for GSI expression, and these results are in agreement with the appearance of a single band per genotype identified in our study. 
Mota et al. (2010) detected the presence of two alleles per cultivar in eight of ten Japanese Plum cultivars analyzed. They plotted a profile of reproductive compatibility among individuals, i.e., the cultivars Santa Rosa (' $S S^{c}$ '), Harry Pickstone (' $S^{b} S^{k}$ ), and América (' $S S^{c}$ ). Although the results of our study show only one fragment amplified by genotype, it was possible to produce groups of genotypes formed from the size of the $S$-allele fragments (Table 2) to verify the similarity between the genotypes studied for $S$-alleles.

Regarding the amplification of the DNA fragment from the S-locus, PC2 produced results that were more comprehensive in the identification groups, although the identification of S-alleles is sometimes difficult to understand in certain genotypes. Molecular studies performed by Mota et al. (2010) identified that the 'Harry Pickstone' and 'America' cultivars were incompatible with each other when comparing reproductive compatibility groups based on the molecular profile of S-alleles. However, according to EPAGRI (Unpublished data), these same cultivars are compatible with each other and used in various orchards of Santa Catarina. Such observed differences in reproductive compatibility based on the molecular profile and phenotypic profile suggests the presence of an additional Quantitative Trait Locus or QTLs (Empresa Brasileira de Pesquisa Agropecuária [EMBRAPA], 2006). Moreover, this trait influences the expression of $S$-alleles and consequently the proteins involved in GSI of Japanese Plum genotypes.

QTLs act on several genes associated with genetic characteristics of agronomic interest, contributing quantitatively to expression of genes linked to fruit weight, pulp tonality and firmness, fruit ripening time (Hernández Mora et al., 2017), grain numbers per pods (Faleiro et al., 2003), and that in recent years the possibility of influence of these QTLs may be associated with GSI (Fernández i Martí et al., 2011), specifically in the linkage group 6 in Prunus (Vilanova et al., 2003), contributing to the expression of S-alleles. As reported by Fernandez i Martí et al. (2014) S-locus can be influenced by epigenetics, characterized by DNA methylation in Prunus genus genotypes, possibly causing loss of $S$-RNase function and promoting reproductive self-compatibility. Therefore, the cultivars identified by Mota et al. (2010) as incompatible with each other, may be phenotypically compatible due to possible influences of DNA methylation, and the environmental conditions in which they are inserted.

The S-locus is multi-allelic, highly polymorphic, and favored genetic variability within the Prunus genus. The complete characterization of the allelic series linked to GSI in the Japanese Plum can support the discovery of genes associated with self-fertility, but we could not sequence the second allele in the studied genotypes. Of the 20 genotypes, 15 genotypes were characterized from the single band identified by PCR. This sequencing allowed us to discover some alleles not yet identified in the Embrapa Selections and to confirm the other alleles studies in previous research, contributing to increase the data library for the $S$-alleles of the species $P$. salicina, from genotypes grown in Southern Brazil. In the following, we describe a little of the $S$-alleles characterized in the genotypes and the inheritances of the alleles by the parents.

The ' $S$ ' allele sequenced in 'Black Amber' may have been inherited from the 'Queen Rosa' cultivar (Table A2), and Halász et al. (2007) observed that Queen Rosa cultivar is one of the parents of Santa Rosa (self-compatible cultivar with alleles ' $S S^{c}$ '). The cultivars Roysum and Fortune presented the ' $S$ ' ' allele, which originated from Mutant Late Santa Rosa and Laroda, respectively (Ramming \& Tanner, 1993; Beppu et al., 2002; Carrasco et al., 2012), is shown in Table A2. Molecular information on S-allele segregation and the register of phenotypic observations are important for understanding GSI in genotypes in studies, although we have not been able to identify the second allele in most cultivars.

The ' $S$ ', allele was characterized in the cultivars Sanguínea, Laroda, SC-15, and Rebelatto. Among these cultivars, we highlight 'Rebelatto', because it presented the ' $S$ ' ' allele, which is associated with GSI (Beppu et al. 2002), but this cultivar is self-compatible. Possibly the second allele not amplified in this cultivar is the $S$-determinant linked to self-fertility. The $S$-allele linked to self-fertility in the cultivar Rebelatto may have been inherited from the parental 'Carazinho', which is a self-fertility cultivar that presented two S-alleles amplified with the PC1, but we were not able to sequence the alleles of this cultivar to conform the alleles linked to self-fertility (Fig. 1). In addition to the ' $S$ ' ' allele in 'Piamontesa' and described by Yamane et al. (1999) is associated with GSI, as well as the ' $S$ ' was featured in 'Chatard', and this allele appears to be involved with GSI (Halász et al. 2007).

Another important group of genotypes that had their DNA fragments sequenced was the SA 86-13, Golden King, Letícia and Robusto where the allele characterized was the ' $S$ '. Letícia is one of the most cultivated genotypes in the southern region of Brazil (EMBRAPA, 2015), and presented the same allele found in Golden King and SA 86-13 (Leticia's sister selection). Klabunde et al. (2014) observed that the cultivar Golden King was possibly one of the parental donors of the S-allele associated with the GSI trait in Letícia (Laetitia ${ }^{\circledR}$, originally from South 
Africa), and the same occurred with the SA 86-13 genotype. The data suggests that the ' $S^{h}$ ' allele was related to self-incompatibility in these genotypes because they are effectively dependent on pollinators in order to get high fruit set.

The identification and characterization of S-alleles in Japanese Plum genotypes are complex and very important for an increased understanding of GSI, and also critical for understanding the influence of female S-haplotypes on the reproduction of the species. Furthermore, it is necessary to study the $S$-determinant since the $S$-locus governs the expression of RNases and F-Box proteins. In addition to the genomic studies, the characterization of physiological aspects related to pollen tube growth, fruit-set and floral synchrony are important for SGI understanding (EMBRAPA, 2008).

During the orchard planting, we have to consider other factors like the combination of cultivars, rootstock, training system, and spacing. The cultivar combination is highly important especially in Brazil, due to the instability of environmental conditions and the limited number of cultivars adapted to the local weather. Moreover, the characterization of Japanese Plum alleles is important for choosing a better cultivar combination to set an orchard and is also an important step in the development of new cultivars in breeding programs. The transfer of S-alleles associated with self-fertility in a Japanese Plum segregating population is necessary for the establishment of cultivars which do not require pollinating plants.

We concluded that the use of PCR for DNA amplification followed by sequencing of S-haplotypes allowed us to identify and characterize the S-alleles that encode the RNases in P. salicina genotypes. The information subsidized reproductive plant management in the field and the breeding programs of Japanese Plum worldwide. However, further studies should be conducted in order to verify if putative QTLs or events like DNA methylation, under different environmental conditions, have an influence on GSI. These complementary investigations may explain and support the breeding improvement of this species.

\section{References}

Aguiar, B., Vieira, J., Cunha, A. E., Fonseca, N. A., Iezzoni, A., Nocker, S. V., \& Vieira, C. P. (2015). Convergent evolution at the gametophytic self-incompatibility system in Malus and Prunus. Plos One., 10(5), 1-24. https://doi:10.1371/journal.pone.0126138

Bakarcic, M., \& De Santis M. A. (1969). Comportamiento a la escaldadura de la hoja de variedades locales de ciruelo. Delta del Parana, 9(12), 35-42.

Beppu, K., Yamane, H., Yaegaki, H., Yamaguchi, M., Kataoka, I., \& Tao, R. (2002). Diversity of S-RNase genes and S-haplotypes in Japanese Plum (Prunus salicina Lindl.). The Journal of Horticultural Science and Biotechnology, 77(6), 658-664. https://dx.doi.org/10.1080/14620316.2002.11511553

Beppu, K., Komatsu, N., Yamane, H., Yaegaki, H., Yamaguchi, M., Tao, R., \& Kataoka, I. (2005). S -haplotype confers self-compatibility in Japanese Plum (Prunus salicina Lindl.). The Journal of Horticultural Science and Biotechnology, 80(6), 760-764. https://doi.org/10.1080/14620316.2005.11512011

Beppu, K., Syogase, K., Yamane, H., Tao, R., \& Kataoka, I. (2010). Inheritance of self-compatibility conferred by the $S^{e}$-haplotype of Japanese plum and development of $S^{e}$-RNase gene-specific PCR primers. Journal of Horticultural Science \& Biotechnology, 85(3) 215-218. https://doi.org/10.1080/14620316.2010.11512657

Carrasco, B., Díaz, C., Moya, M., Gebauer, M., \& González, R. G. (2012). Genetic characterization of Japanese Plum cultivars (Prunus salicina) using SSR and ISSR molecular markers. Ciencia e Investigación Agraria, 39(3), 533-543. https://doi.org/10.4067/S0718-16202012000300012

Dabrowski, M. J., Bornelov, S., Kruczyk, M., Baltzer, N., \& Komorowski, J. (2015). 'True’ null allele detection in microsatellite loci: A comparison of methods, assessment of difficulties and survey of possible improvements. Molecular Ecology Resources, 15(3), 477-488. https://doi: 10.1111/1755-0998.12326

De Conti, D., Ribeiro, M. F., Raseira, M. C. B., Peters, J. A., \& Bianchi, V. J. (2013). Identificação por PCR dos alelos-S associados à compatibilidade gametofítica em ameixeira japonesa. Pesquisa Agropecuária Brasileira, 48(10), 1360-1367. https://doi.org/10.1590/S0100-204X2013001000007

De Nettancourt, D. (2001). Incompatibility and incongruity in wild and cultivated plants (2nd ed.). Berlin: Springer. https://doi.org/10.1007/978-3-662-04502-2

Doyle, J. J., \& Doyle, J. L. (1991). Isolation of plant DNA from fresh tissue. Focus, 1(2), 13-15. 
Embrapa (Empresa Brasileira de Pesquisa Agropecuária). (2006). Mapeamento genético de caracteres quantitativos e sua interação com o ambiente. Planaltina, DF: Empresa Brasileira de Pesquisa Agropecuária, Cerrados.

Embrapa (Empresa Brasileira de Pesquisa Agropecuária). (2008). Ameixeira: Cultivares indicadas para plantio nas regiões produtoras brasileiras. Pelotas, RS: Empresa Brasileira de Pesquisa Agropecuária, Clima Temperado.

Embrapa (Empresa Brasileira de Pesquisa Agropecuária). (2015). Avaliação Agronômica da Ameixeira 'Letícia' em Vacaria, RS. Pelotas, RS: Empresa Brasileira de Pesquisa Agropecuária, Clima Temperado.

Faleiro, F. G., Schuster, I., Ragagnin, V. A., Cruz, C. D., Corrêa, R. X., Moreira, M. A., \& Barros, E. G. (2003). Caracterização de linhagens endogâmicas recombinantes e mapeamento de locos de características quantitativas associados a ciclo e produtividade do feijoeiro-comum. Pesquisa Agropecuária Brasileira, 38(12), 1387-1397. https://doi.org/10.1590/S0100-204X2003001200005

Fernández i Martí, A., Hanada, T., Alonso, J. M., Yamane, H., Tao, R., \& Socias i Company, R. (2009). A modifier locus affecting the expression of the S-RNase gene could be the cause of breakdown of self-incompatibility in almond. Sexual Plant Reproduction, 22(3), 179-186. https://doi.org/10.1007/ s00497-009-0102-7

Fernández i Martí, A., Gradziel, T. M., \& Socias i Company, R. (2014). Methylation of the $\mathrm{S}_{\mathrm{f}}$ locus in almond is associated with S-RNase loss of function. Plant Molecular Biology, 86(6), 681-689. https://doi.org/10.1007/ s11103-014-0258-x

Gonçalves, E. G., \& Lorenzi, H. (2011). Morfologia Vegetal: Organografia e dicionário ilustrado de morfologia das plantas vasculares (2nd ed.). Nova Odessa: Instituto Plantarum de Estudos da Flora Ltda.

Gu, C., Wang, L., Korban, S. S., \& Han, Y. (2015). Identification and characterization of S-RNase genes and S-genotypes in Prunus and Malus species. Canadian Journal of Plant Science, 95(2), 213-225. https://doi.org/10.4141/cjps-2014-254

Guerra, M. E., Wünsch, A., \& López-Corrales, M. (2010). Self-incompatibility in Japanese Plum-S-Allele Genotyping of cultivars. Acta Hortic., 874, 169-174. https://doi.org/10.17660/ActaHortic.2010.874.23

Halász, J., Hegedus, A., Nyéki, Z. S. J., \& Pedryc, A. (2007). DNA-based s-genotyping of Japanese Plum and pluot cultivars to clarify incompatibility relationships. HortScience, 42(1), 46-50. https://doi.org/10.21273/ hortsci.42.1.46

Havlícková, L., Jozová, E., Klíma, M., Kucera, V., \& Curn, V. (2014). Detection of self-incompatible oilseed rape plants (Brassica napus L.) based on molecular markers for identification of the class I S-haplotype. Genetics and Molecular Biology, 37(3), 556-559. https://doi.org/10.1590/S1415-47572014000400012

Hernández Mora, J. R., Micheletti, D., Bink, M., Weg, E. V., Cantín, C., Nazzicari, N., Caprera, A., ... Aranzana M. J. (2017). Integrated QTL detection for key breeding traits in multiple peach progenies. Bio Med Genomics, 18(404), 1-15. https://doi.org/10.1186/s12864-017-3783-6

Hua, Z. H., Fields, A., \& Kao, T. H. (2008). Biochemical Models for S-RNase-Based Self-Incompatibility. Molecular Plant, 1(4), 575-585. https://doi.org/10.1093/mp/ssn032

Kondo, K., Yamamoto, M., Itahashi, R., Sato, T., \& Egashira, H. (2002). Insights into the evolution of self-compatibility in Lycopersicon from a study of stylar factors. The Plant Journal, 30(2), 143-53. https://doi.org/10.1046/j.1365-313X.2002.01275.x

Kodad, O., Sánchez, N., Saibo, N., Oliveira, M., \& Socias I Company, R. (2008). Identification and characterization of new S-alleles associated with self-incompatibility in almond. Plant Breeding, 127(6), 632-638. https://doi.org/10.1111/j.1439-0523.2008.01541.x

Klabunde, G. H. F., Dalbó, M. A. \& Nodari, R. O. (2014). DNA fingerprinting of Japanese Plum (Prunus salicina) cultivars based on microsatellite markers. Crop Breeding and Applied Biotechnology, 14(3), 139-145. https://doi.org/10.1590/1984-70332014v14n3a21

López, M., Mnejja, M., Rovira, M., Collins, G., Vargas, F. J., Arús, P., \& Batlle, I. (2004). Self-incompatibility genotypes in almond re-evaluated by PCR, stylar ribonucleases, sequencing analysis, and controlled pollinations. Theoretical and Applied Genetics, 109(5), 954-964. https://doi.org/10.1007/s00122-004$1656-2$ 
Luhtala, N., \& Parker, R. (2010). T2 Family ribonucleases: Ancient enzymes with diverse roles. Trends in Biochemical Science, 35(5), 253-259. https://doi.org/10.1016/j.tibs.2010.02.002

Madureira, H. C. (2009). Caracterização celular e molecular do sistema de auto-incompatibilidade esporofitica do maracujazeiro azedo (Passiflora edulis Sims) (Doctoral thesis, Genética e Melhoramento de Plantas, Universidade Estadual do Norte Fluminense Darcy Ribeiro, Campo dos Goytacazes, Rio de Janeiro).

Matsuura, T., Sakai, H., Unno, M., Ida, K., Sato, M., \& Sakiyama, F. S. (2001). Crystal Structure at 1.5-Å Resolution of Pyrus pyrifolia Pistil Ribonuclease Responsible for Gametophytic Self-incompatibility. The Journal of Biological Chemistry, 276(48), 45261-45269. https://doi.org/10.1074/jbc.M107617200

Marchese, A., Boskovic, R. I., Martínez-García, P. J., \& Tobutt, K. R. (2008). The origin of the self-compatible almond 'Supernova'. Plant Breeding, 127, 105-107. https://doi.org/10.1111/j.1439-0523.2008.01421.x

Mota, M. S., Bianchi, V. J., Carvalho, A. Z., Braga, E. J. B., \& Peters, J. A. (2010). Caracterização molecular dos alelos-S de incompatibilidade gametofítica em Prunus salicina Lindl. Revista Brasileira de Fruticultura 32(3), 798-807. https://doi.org/10.1590/S0100-29452010005000096

Mittler, R., Vanderauwera, S., Suzuki, N., Miller, G., Tognetti, V. B., Vandepoele, K., ... Breusegem, F. V. (2011). ROS signaling: The new wave? Trends in Plant Science, 16(6), 1360-1385. https://doi.org/10.1016/ j.tplants.2011.03.007r

Mcclure, B. A., Cruz-García, F., \& Romero, C. (2011). Compatibility and incompatibility in S-RNase-based systems. Annals of Botany, 108(4), 647-658. https://doi.org/10.1093/aob/mcr179

Okie, W. R., \& Ramming, D. W. (1999). Plum breeding worldwide. HortTechnology, 9(2), 162-176. https://doi.org/10.21273/horttech.9.2.162

Ramming, D. W., \& Tnner, O. (1993). 'Fortune' Plum. HortScience, 28(6), 679. https://doi.org/10.21273/ HORTSCI.28.6.679

Sapir, G., Stern, R. A., Eisikowitch, D., \& Goldway, M. (2004). Cloning of four new Japanese Plum S-alleles and determination of the compatibility between cultivars by PCR analysis. Journal of Horticultural Science and Biotechnology, 79(2), 223-227. https://doi.org/10.1080/14620316.2004.11511752

Sassa, H. (2016). Molecular mechanism of the S-RNase-based gametophytic self-incompatibility in fruit trees of Rosaceae. Breeding Science, 66(1), 116-121. https://doi.org/10.1270/jsbbs.66.116

Suzuki, M. M., \& Bird, A. (2008). DNA methylation landscapes: Provocative insights from epigenomics. Nature Reviews Genetic, 9(6), 465-476. https://doi.org/10.1038/nrg2341

Schifino-Wittmann, M. T., \& Dall'gnol, M. (2002). Auto-incompatibilidade em plantas. Ciência Rural, 32(6), 1083-1090.

Takayama, S., \& Isogai, A. (2005). Self-Incompatibility in Plants. Annual Review Plant Biology, 56, 467-89. https://doi.org/10.1146/annurev.arplant.56.032604.144249

Tao, R., Yamane, H., Sugiura, A., Murayama, H., Sassa, H., \& Mori, H. (1999). Molecular Typing of S-alleles through Identification, characterization and cDNA cloning for S-RNases in Sweet Cherry. Journal of the American Society Horticultural Science, 124(3), 224-233. https://doi.org/10.21273/jashs.124.3.224

Thompson, J. D., Gibson, T. J., Plewniak, F., Jeanmougin, F., \& Higgins, D. G. (1997). The CLUSTALX windows interface: Flexible strategies for multiple sequence alignment aided by quality analysis tools. Nucleic Acids Research, 25(24), 4876-4882. https://doi.org/10.1093/nar/25.24.4876

Ushijima, K., Sassa, H., Tao, R., Yamane, H., Dandekar, A. M., Gradziel, T. M., \& Hirano, H. (1998). Cloning and characterization of cDNAs encoding S-RNases from almond (Prunus dulcis): primary structural features and sequence diversity of the S-RNases in Rosaceae. Molecular and General Genetic, 260(2), 261-268. https://doi.org/10.1007/s004380050894

Watari, A., Hanada, T., Yamane, H., Esumi, T., \& Tao, R. (2007). A Low Transcriptional Level of $S^{e}$-RNase in the $S$-haplotype Confers Self-compatibility in Japanese Plum. Journal American Society for Horticultural Science, 132(3), 396-406. https://doi.org/10.21273/JASHS.132.3.396

Williams, J. S., Wu, L., Li, S., Sun, P., \& Kao, T. H. (2015). Insight into S-RNase-based self-incompatibility in Petunia: Recent findings and future directions. Frontiers in Plant Science, 5(6), 41-47. https://doi.org/ $10.3389 /$ fpls.2015.00041 
Wu, J., Gu, C., Khan, M. A., Wu, J., Gao, Y., Wang, C., Korban, S. S., \& Zhang, S. (2013). Molecular determinants and mechanisms of gametophytic self-incompatibility in fruit trees of Rosaceae. Critical Reviews in Plant Sciences, 32(1), 53-68. https://doi.org/10.1080/07352689.2012.715986

Yamane, H., Tao, R., \& Sugiura, A. (1999). Identification and cDNA Cloning for S RNases in Self-incompatible Japanese Plum (Prunus salicina Lindl. cv. Sordum). Plant Biotechnology, 16(5), 389-396. https://doi.org/ 10.5511/plantbiotechnology.16.389

Yamane, H., Tao, R., \& Sugiura, A. (2001). Identification and characterization of S-RNases in tetraploid sour Cherry (Prunus cerasus). Journal of the American Society Horticultural Science, 126(6), 661-667. https://doi.org/10.21273/jashs.126.6.661

Zang, S. L., Huang, S. X., Kitashiba, H., \& Nishio, T. (2007). Identification of S-haplotype-specific F-box gene in Japanese plum (Prunus salicina Lindl.). Sex Plant Reproduction, 20, 1-8. https://doi.org/10.1007/ s00497-006-0037-1

\section{Appendix A}

Table A1. S-alleles identified in P. salicina genotypes, with two primer combinations; S-RNAse identified; (\%) identity (ID); (\%) Query Cover (QC); access to the sequences of the alleles, with the e-value and of the respective authors that deposited the data in NCBI

\begin{tabular}{|c|c|c|c|c|c|c|c|c|c|c|}
\hline GENOTYPES & PC1 & S-RNase & ID & QC & ACCESS & PC2 & S-RNase & ID & QC & ACCESS \\
\hline Sel. Embrapa A19 & 663 & $S^{c}$ & 100 & 100 & DQ646489.1 & $*$ & $*$ & $*$ & $*$ & $*$ \\
\hline Sel. Embrapa A28 & 565 & $S^{c}$ & 99 & 99 & DQ646489.1 & 550 & $S^{c}$ & 100 & 100 & AB280791.1 \\
\hline Black Amber & 790 & $S^{c}$ & 96 & 99 & $\underline{\mathrm{AF} 432418.1}$ & 470 & $S^{c}$ & 94 & 100 & $\underline{\mathrm{AF} 432418.1}$ \\
\hline Sanguínea & 324 & $S^{i}$ & 99 & 99 & $\underline{\mathrm{AB} 084149.1}$ & 492 & $S^{i}$ & 95 & 100 & $\underline{\mathrm{AB} 084149.1}$ \\
\hline Laroda & 299 & $S^{i}$ & 99 & 100 & $\underline{\mathrm{AB} 084149.1}$ & 467 & $S^{i}$ & 94 & 94 & $\underline{\mathrm{AB} 084149.1}$ \\
\hline Piamontesa & 363 & $S^{a}$ & 99 & 93 & AB252411.1 & 522 & $S^{a}$ & 99 & 100 & AB252411.1 \\
\hline SA $86-13$ & 414 & $S^{h}$ & 96 & 99 & DQ790374.1 & 613 & $S^{h}$ & 100 & 98 & AB084148.1 \\
\hline Golden King & 275 & $S^{h}$ & 95 & 85 & DQ790374.1 & 381 & $S^{h}$ & 97 & 100 & $\underline{\mathrm{AB} 084148.1}$ \\
\hline Chatard & 204 & $S^{a}$ & 93 & 100 & AB252411.1 & 524 & $S^{a}$ & 99 & 100 & AB252411.1 \\
\hline Letícia & 396 & $S^{h}$ & 97 & 97 & DQ790374.1 & 566 & $S^{h}$ & 98 & 100 & $\underline{\mathrm{AB} 084148.1}$ \\
\hline Robusto & 407 & $S^{h}$ & 98 & 100 & DQ790374.1 & 509 & $S^{h}$ & 99 & 100 & $\underline{\mathrm{AB} 084148.1}$ \\
\hline Fortune & 487 & $S^{c}$ & 94 & 100 & AF432418.1 & 516 & $S^{c}$ & 99 & 95 & $\underline{\mathrm{AB} 280791.1}$ \\
\hline Roysum & 481 & $S^{c}$ & 98 & 100 & AF432418.1 & 435 & $S^{c}$ & 97 & 96 & AB280791.1 \\
\hline SC-15 & 292 & $S^{i}$ & 98 & 99 & $\underline{\mathrm{AB} 084149.1}$ & 480 & $S^{i}$ & 94 & 92 & $\underline{\mathrm{AB} 084149.1}$ \\
\hline Rebelatto & 304 & $S^{i}$ & 96 & 99 & $\mathrm{AB} 084149.1$ & 497 & $S^{i}$ & 97 & 100 & AB084149.1 \\
\hline
\end{tabular}

Note. Combination of primers PC1 (Pru-C2 + PCE-R) and PC2 (Pru-C2 + Pru-C5) in base pairs. (*) Satisfactory sequencing data were not obtained for this cultivar and combination of primers. 
Table A2. Identification of Prunus salicina Lindl genotypes with approximate PCR amplified pairs with the combination of PRU-C2 + PCE-R (PC1) and PRU-C2 + PRU-C5 (PC2) primers, in addition to the country of origin and the parents

\begin{tabular}{|c|c|c|c|c|c|}
\hline Genotypes & BP (PC1) & BP (PC2) & Countries & Parents & References \\
\hline Selection Embrapa A19 & 1200 & 1300 & Brazil & Free pollination of Pluma 2 & Unknown \\
\hline Selection Embrapa A28 & 1200 & 1300 & Brazil & Free pollination of Pluma 2 & Unknown \\
\hline Selection Embrapa A7 & $300 \& 250$ & 600 & Brazil & Free pollination of Pluma 2 & Unknown \\
\hline Black Amber & 1200 & 1300 & USA & Friar $\times$ Queen Rosa & Halász et al., 2007 \\
\hline Carazinho & $400 \& 300^{* *}$ & 600 & Brazil & Unknown origin & Dalbó et al., 2010 \\
\hline Sanguínea & 300 & 600 & Brazil & Unknown origin & Klabunde et al., 2014 \\
\hline Bruce & $*$ & $*$ & USA & Prunus salicina $\times$ Prunus angustifolia & Zarrouk et al., 2006 \\
\hline Laroda & 300 & 600 & USA & Santa Rosa $\times$ Gaviota & Beppu et al., 2002 \\
\hline Piamontesa & 400 & 650 & Argentina & Unknown origin & Klabunde et al., 2014 \\
\hline SA $86-13$ & 400 & 700 & South Africa & Free pollination of Golden King & Klabunde et al., 2014 \\
\hline Golden King & 400 & 700 & Australia & Unknown origin & Okie \& Ramming, 1999 \\
\hline Chatard & 350 & 650 & Argentina & Unknown origin & Bakarcic \& De Santis, 1969 \\
\hline Letícia & 400 & 700 & South Africa & Free pollination of Golden King & Klabunde et al., 2014 \\
\hline Robusto & 300 & 700 & USA & $\begin{array}{l}(\text { Queen Ann } \times \text { Barstow }) \times \\
(\text { O. Premier } \times \text { P. angustifolia })\end{array}$ & Carrasco et al., 2012 \\
\hline Fortune & 1200 & 1300 & USA & Laroda $\times$ B65-11 & Ramimg \& Tanner, 1993 \\
\hline Roysum & 1100 & 1300 & USA & Mutante da Late Santa Rosa & Carrasco et al., 2012 \\
\hline SC-15 & 300 & 600 & Brazil & $\begin{array}{l}\text { Seleção 93-1-8-29 } \\
(\text { Chatard } \times \text { Angeleno })\end{array}$ & Unknown \\
\hline SC-7 & 1200 & 1500 & Brazil & Letícia $\times$ Piamontesa & Unknown \\
\hline Zafira & 1200 & 1500 & Brazil & SC- $7 \times$ Fortune & Unknown \\
\hline Rebelatto & 300 & 600 & Brazil & Amarelinha $\times$ Carazinho & Unknown \\
\hline
\end{tabular}

Note. $(*)$ the cultivars did not present bands amplification with the combination of primers tested. $(* *)$ the cultivars presented two amplified bands in our PCR conditions.

\section{Copyrights}

Copyright for this article is retained by the author(s), with first publication rights granted to the journal.

This is an open-access article distributed under the terms and conditions of the Creative Commons Attribution license (http://creativecommons.org/licenses/by/4.0/). 